\title{
Challenges of Religious Literacy in Education: Islam and the Governance of Religious Diversity in Multi-faith Schools
}

\author{
Inkeri Rissanen, Martin Ubani, and Tuula Sakaranaho
}

\begin{abstract}
This chapter seeks take part in an emerging research where religion is approached as a whole school endeavor. Previous research and policy recommendations typically focused on teaching about religion in school, but the accommodation of religious diversity in the wider school culture merits more attention. Based on observations in our multiple case studies, we discuss the multi-level governance of religious diversity in Finnish multi-faith schools with a particular focus on the challenges of religious literacy for educators. The three examples we present focus on the inclusion of Muslims in Finnish schools and in particular on the challenges for educator (1) in interpreting the distinction between religion and culture, (2) in recognizing and handling intra-religious diversity, and (3) in being aware of Protestant conceptions of religion and culture. A theme cutting across these examples is how they reflect the tendencies either to see different situations merely through the lens of religion (religionisation), or not to recognize the importance of religion at all (religion-blindness). We argue that religious literacy should be recognized and developed as a vital part of the intercultural competencies of educators.
\end{abstract}

Keywords Multi-faith schools $\cdot$ Religious diversity $\cdot$ Governance $\cdot$ Religious literacy $\cdot$ Islam

\section{Introduction}

During recent decades, Finnish society has become increasingly multicultural and multireligious. Due to this there have been some changes to Finnish legislation, so that the Freedom of Religion Act was renewed, together with acts for basic, secondary and

\footnotetext{
I. Rissanen ( $₫)$

Tampere University, Tampere, Finland

e-mail: inkeri.rissanen@tuni.fi
}

M. Ubani

University of Eastern Finland, Joensuu, Finland

T. Sakaranaho

University of Helsinki, Helsinki, Finland 
upper-secondary schools, at the beginning of the twenty-first century (see Sakaranaho 2013). Thus, the growing diversity of Finnish society has been acknowledged by the state, and legal adjustments made accordingly, in education among other areas. On a more practical level, however, recent reports highlight that schools and teacher education in Finland have not adapted sufficiently to the changed demographics of Finnish society (Tainio and Kallioniemi 2019; Räsänen et al. 2018). An important part of this shift concerns the growing number of students belonging to different religions. In current research, religious diversity in education has mainly attracted attention in relation to religious education in state-supported schools (Sakaranaho 2013; Rissanen et al. 2019). Furthermore, while Europe-wide recommendations for policy and practices for teaching about religions in European schools have emerged (Jackson 2014; OSCE/ODIHR 2007), these do not address the accommodation of religious diversity in the wider school culture. Instead of maintaining the rather narrow focus on religious education, this chapter takes part in an emerging research where religion is approached as a whole-school endeavour (Ubani and Ojala 2018). Religion as a whole-school endeavour, moreover, will be discussed from the point of view of religious literacy and multi-level governance, which to date have not received enough attention in research on religious diversity and education in Finland. In doing so, it will widen the perspective of current international discussion on religious literacy that focuses on religious education to religious literacy in relation to a school community as a whole (cf. Biesta et al. 2019).

Religious literacy is about the ability to "discern and analyse the fundamental intersections of religion and social/political/cultural life through multiple lenses" (Moore 2015, 30). As a result of the process of secularisation in Europe, however, religious literacy as a civic competence is getting weaker or lacking altogether (Dinham and Francis 2015), resulting in a sort of illiteracy with regards to religion in public space. In the field of education, criticism of secular normativity (i.e. the othering of nonsecular worldviews in educational thinking and practices) has emerged along with discussions about post-secular society (Berglund 2017; Poulter et al. 2016; Rissanen 2018). Finland can be described as a post-secular society in which the secular system of governance is encountering increasing religious diversity and a rising public presence of religion (see Nynäs et al. 2015). The Finnish state has official multicultural policies that extend to efforts to support different cultural and religious identities in schools. In practice, however, a gap exists between the official recognition of religious diversity by the state and the religious minorities' experiences of inclusion in schools (Rissanen et al. 2016; Rissanen 2018, 2019). It is our contention that discrepancies such as this invite an analysis of religious literacy as a relevant component in the skillset of education professionals in a post-secular context.

The challenge of religious literacy is apparent when looking at teachers and principals in Finland, for whom, as education professionals, religion seems to be a difficult matter to cope with. The struggle to come to terms with religion is particularly apparent in relation to growing religious diversity in Finnish schools, where Islam is seen as one of the main challenges. Contemporary education professionals have grown up and been educated in the rather monocultural atmosphere of Finland, which has not been the best environment for the development of religious literacy as a part 
of intercultural competence. It is also important to recognise that education professionals, on the main, share the position of the majority, possessing certain inherited cultural, ideological and religious values that shape their personal worldviews as well as the educational practices in general (Rissanen et al. 2015, 2016). However, due to growing cultural diversity in Finnish society, the state policies make demands on principals and teachers to come to terms with this diversity and fashion the management of teaching in schools accordingly. Moreover, principals and teachers in their everyday work are faced with pupils who, especially in the major cities in Finland, have grown up in a culturally diverse environment where different religiously based values, beliefs and practices (i.e. dress codes and dietary habits) are an elementary part of their everyday life at school. Consequently, in order for education professionals to successfully come to terms with and manage the growing religious diversity in Finnish schools, it is important to develop their intercultural skills-and religious literacy as a part of those skills.

Due to rapid social changes, intercultural competence has in recent decades become commonly acknowledged as a key component of education professionals' competence as an "ability to effectively and appropriately interact in an intercultural situation or context" (Berry and Southwell 2011, 453). In short, the focus of intercultural competence lies in encounters between persons with different identity markers in different contexts. However, with respect to Finland, the role of religion as an identity marker, and as a possible dimension of culture, has not received sufficient attention in research on multicultural education in general and on teachers' intercultural competence in particular (Rissanen et al. 2016). All in all, even though teachers in Finland are highly respected professionals with a strong ethical orientation and willingness to promote equality in education (Kuusisto et al. 2012), and the high quality of Finnish teacher education has become internationally recognised, developing teachers' abilities to deal with cultural and religious diversity can be underlined as an area that needs more attention.

Concerning intercultural competence, it is important to look at the challenges of religious literacy among education professionals (teachers and principals). We will investigate these in light of three examples from Finnish schools. These examples focus on the inclusion of Muslims in Finnish schools and, in particular, on the challenges in: (1) interpreting the distinction between religion and culture, (2) recognizing and handling intra-religious diversity, and (3) awareness of Protestant conceptions of religion and culture. A theme that cuts across these examples is how they reflect the tendencies either to see different situations merely through the lens of religion (religionisation) or not to recognise the importance of religion at all (religion-blindness).

Investigation of the aforementioned examples is based on qualitative data that we have collected in Finnish schools in our recent research projects. The first set of data concerns the inclusion of Muslims in Finnish and Swedish schools. Altogether 36 interviews were conducted with school principals $(\mathrm{n}=10$ in both countries) and Muslim parents ( $\mathrm{n}=8$ in both countries), who were positioned as mediators or "cultural interpreters" in their school communities. This data was analysed from the perspective of negotiations regarding the inclusive citizenship of Muslims (Rissanen 
2018) and different ideologies of diversity held by school principals (Rissanen 2019). The second set of data focuses on the discrepancies between educational policy and practice in issues related to the role of multiculturalism and religion in school. The data was collected in a school in the metropolitan area of Helsinki by means of ethnographic enquiry lasting one year, including interviews and observation. It also includes quantitative data based on different members of a school community. In addition, we also studied the policy documents concerning public education in Finland (Ubani 2013, 2018).

\section{Public Schools and the Governance of Religious Diversity}

Coming to terms with growing religious diversity in Finnish public schools involves different processes of governance, as the top-down policies implemented by the state are not enough. Instead, a pluricentric governance based on interdependence and negotiation is needed (see Torfing 2007; see Bell and Hindmoor 2009; Sakaranaho 2019). Hence, it is crucial to be aware of and look at different processes of steering and implementation of school policies, which are undertaken not only by the state but even more importantly by the municipalities and education professionals (see Sakaranaho and Martikainen 2015; Sakaranaho 2018, 2019).

Finland employs a Nordic type of state-supported comprehensive public education where the aim is the equal education of all members of society. The role of schools in implementing state policies on the governance of education has been discussed extensively in research that highlights the issues related to citizenship, social cohesion and the agenda of self-preservation of the nation-state (Mundy 2007; Weymann 2013). In the formation of the Nordic welfare state, a sense of nationhood has also been connected with the development of a strong public school system (Buchardt et al. 2013).

The basis for the current Finnish public education was developed in the 1860s during a period of Finnish national awakening. As part of this development, the responsibility for public compulsory education was shifted from the Evangelical Lutheran Church of Finland to the municipalities. From there on, comprehensive education in Finland has been an organic part of the state governance. The last extensive reform of the Finnish educational system was undertaken in the early 1970s, when the current system of comprehensive education was developed. In accordance with this, the whole population of Finland would study from 7 to 16 years of age in a uniform school system. (Sakaranaho 2013.)

The current Finnish curriculum for basic education articulates diversity as a feature of all students, and it demands the recognition of different religious and cultural identities. In comparison with the Swedish curriculum, which is rather silent about diversity and makes a distinction between the students' "own origins" and the "common heritage" (with the latter including "basic values of Swedish society") in a relatively essentialising manner, the discourse employed in the Finnish curriculum can be described as non-essentialist and multiculturalist (Zilliacus et al. 2017). Recent 
research has pointed out that the ideal of strengthening cultural diversity is one of the overarching aims of the current Finnish basic education system (Mäkelä et al. 2017). When compared with the previous National Core Curriculum for Basic Education (henceforth NCCBE), there is strong emphasis on culture in the current curriculum (NCCBE 2004, 2014; Ubani 2012). In the recent curriculum, students are to "be educated for a world that is diverse in terms of culture, language, religion and convictions" and to view "cultural diversity in principle as a positive resource" (NCCBE 2014, 21).

Similarly to the current national core curriculum, in general the Finnish state policy documents address issues regarding religious, cultural, linguistic and ethnic diversity (Ubani 2013; Sakaranaho 2013). In fact, as mentioned in the introduction, several reports have placed Finland among the leaders in Europe in integration policies and also in minority rights (Multiculturalism Policy Index 2010; Migrant Integration Policy Index 2015; Varjonen et al. 2017). However, there have been strong concerns about the implementation of such policies in practice (Fagioli-Ndlov 2015, 13). The higher-level policies act as a framework, while schools are one of the implementation contexts for how the national policies concerning multiculturalism and religion are interpreted by the municipalities.

The central role of the state notwithstanding, the daily management and operation of schools in Finland are municipality-based. Hence, the municipalities oversee the application of the generic national guidelines in the Basic Education Act issued by the Ministry of Education and Culture, from the descriptions of general goals and time allocation in instruction and the national core curriculum to daily practices in schools. In addition to state schools, the municipalities oversee private schools as well. (Vitikka et al. 2012; Ubani 2013.) The important role of the municipalities in relation to education is also evident in that municipalities in larger cities have their own guidelines concerning the management of religion in schools; therefore, guidelines may differ from one municipality to the next. As an example, one can cite the question of girls' swimming lessons or absences due to religious festivals. These guidelines may include booklets, in-service training for principals, teachers and other personnel, and maintaining an open or closed web portal. (Ubani 2018; Mäkelä et al. 2017.)

To sum up, when compared to many other European countries, Finnish educational policy is characterised by a rather uniform educational structure. In this system, the state officials at different levels of the administration interpret and implement the policies without much negotiation with civil society. However, the one special case in this quite uniform implementation system seems to be the governance of religious diversity in schools (see Sakaranaho 2018). In schools, principals act relatively autonomously when outlining the different practices. Therefore, there can be great variations in school practices with regards to religion in different public schools, even in the area of one municipality. Unlike in many other countries, in Finland there is no system of monitoring schools and their instruction. Instead, the educational system is based on trust in the professionalism of teachers (Husu and Toom 2012). This also gives room for principals to make individual decisions with regards to the handling of religions in their school that diverges from practices in neighbouring schools. 
While in recent years there has been a policy-driven aim to increase civil participation in governance of different fields of society, in public education the autonomy of the educational professionals remains rather uncontested. However, in order for the governance of religious diversity to be in line with the general notion of trust in the educational system, teachers' professionalism should incorporate religious literacy as part of intercultural competence. The following examples analyse some challenges in religious literacy among educational professionals and, accordingly, highlight issues where it is in need of development.

\section{Distinction Between Religion and Culture}

In the current world, the relationship between religion and culture has become more complex. On the one hand, new cultural paradigms emphasise the need to recognise the fluidity and internal diversity of religions and individuality of their followers, but the reaction to this has also been the "deculturalization of religion", with people of faith defending the authenticity and universality of their tradition (Roy 2010). Thus, distinguishing between religion and culture has political implications, and it demands religious literacy. In the field of religious education, the way in which religions should be represented and investigated in the classroom - as cultural phenomena or with a focus on doctrines and truth claims - has been a much discussed issue. The cultural approaches have been accused of misrepresenting religion in a way that does not teach respect for differences (e.g. Wright 2004; Barnes 2006). By contrast, how the ways of distinguishing between religion and culture steer the governance of religious diversity in the larger school community is a less explored area, and it is our focus here. We have observed how educators sometimes make distinctions between religion and culture in a simplified and strategic manner. Some school principals legitimize their assimilative demands by interpreting certain behaviour of parents or students as "cultural" and, therefore, they reduce the importance of this behaviour and move it outside the scope of religious freedom. In our studies, for instance, some principals interpreted Muslim parents' unwillingness to shake hands with the opposite sex as "only a cultural issue", and this interpretation was used as an argument to justify their demand that adapting to the common way of greeting in the country is something that can be expected from the parents (Rissanen 2019). Most of the Muslim parents in our data did greet the opposite sex by shaking hands and did not consider this a problem, but there were also those who regarded the choice to not touch the opposite sex as a right based on their religious freedom.

As an example, one can mention a female principal who recollected how some Muslim fathers were not willing to shake hands with her. When she was asked how she handled the situation, she described that when a certain father had refused to shake hands with her, at first she let him come to her office but later when the father's unwillingness to shake hands with her continued, she did not invite him to her office but instead had a discussion with him in the corridor as a sign of displeasure. It should be noted that on no occasion did the principal in question explain to the father why 
she behaved with him the way she did. It is evident that the principal associated not shaking hands with the unequal treatment of women and thus experienced it very negatively (Ubani forthcoming).

Religious literacy can facilitate awareness of different types of behaviour among Muslims but perhaps also more nuanced interpretations of the reasons, in this case, for not shaking hands. Instead of showing a lack of respect for the opposite sex, many of our Muslim informants interpreted not shaking hands with the opposite sex as an act of respect. Thus, the same behaviour can lead to opposite interpretations, and if there is no communication between the involved parties, it can cause grave misunderstandings and, in the worst cases, even conflict. The aim in developing religious literacy is to avoid such unfortunate outcomes.

On the other hand, we also observed occasions of where certain cultural issues were "religionised". Often the most identifiable and distinctive expression of what is considered religion - but is rather an interplay of religion, culture, ethnicity, nationality and minority position - becomes religionised and reified as a normative assumption. There were situations where teachers gave examples of frictions between Somali families in school, which in their view were based on religion-and Islam, in particular-but in reality were connected to clan division. The interpretations of these frictions also highlighted the way in which teachers see Somalis as a uniform group. A case in point happened when some Somali mothers came to the school and demanded that their daughters should not be allowed to play with some other Somali children. The teachers knew that the division in this conflict was based on clan membership but nonetheless interpreted that the incident was in fact caused by religion (specifically Islam). This particular case reflects a general tendency to explain conflicts and, more generally, any inappropriate behaviour of Muslim students solely in terms of religion and hence to 'religionise' their behaviour (Ubani 2015).

It has to be admitted that the problems of religionisation are recognised by some professionals in schools, who endeavour to overcome it by emphasising the irrelevance of Muslim identity. For example, many Finnish education professionals are critical toward the current separative approach to religious education for the reason that it makes Muslim identities "too visible" (Rissanen 2019). The ethos of secular normativity is exemplified by the fact that even many of those professionals who support the "celebration of diversity" in school leave religious identity markers out of it.

However, we noticed that there are clear differences in how distinctions between religion and culture are interpreted with respect to the (imagined) majority religion and minority religions. Protestant Christianity continues to play a significant (although continuously debated) role as an important source of tradition and as an identity marker in the school culture, whereas Islam hardly ever does. On the contrary, many principals perceived Islam as essentially religious and, therefore, not having pedagogical relevance as an aspect of cultural heritage or as an identity marker of the students that could be positively recognised. In other words, the intersections of religion with other identity markers is recognised in the case of the majority religion, but not in the case of Islam. The inability to recognise the role of Islam as a cultural element or identity marker also relates to principals' perceptions, according to which 
"Islam is not a tradition here", reflecting a continued understanding of Islam as alien to the Nordic context. Due to this "secular Protestant normativity", in many Finnish schools Muslim identities thus become visible only through restrictions and the difficulties that their incorporation into the school culture entails. According to the views of Muslim parents and teachers, this makes it difficult to increase knowledge about Islam and counter the stigma attached to Muslim identities (Rissanen 2018, 2019).

\section{Intra-religious Diversity}

Another issue that is much discussed in the scholarly field of religious education but less explored as affecting an entire school is the recognition or misrecognition of intra-religious diversity. Representation of religions as monolithic entities can maintain stereotypes and prejudices, but it can also be used as a strategy to counter those by representing sympathetic and "sanitised" versions of religions (Revell 2012). We have observed the inability of educators to recognize intra-religious diversity in the everyday life of schools. As a result, religious diversity is governed in a way that does not offer justice to individual pupils and families and may even violate their freedom concerning religious convictions and expressions, as well as the heritage of their cultural and national origins. For instance, in a school with many Somali Muslims, "religion" easily equals "Islam" and "Muslim" equals "Somali". In this case, the Somali way of practising religion is regarded as an orthopraxis of Islam, the tenets of which all other Muslims are then expected to follow. In this type of school, Islam is sometimes regarded as an internal attribution that connotes aspects related to, for instance, challenges in social integration, language and learning. In concrete terms, this means that the challenges experienced among some Somalis in Finnish society are also attributed to Muslim students from other ethnic communities (Ubani 2018, 2019).

An overly simplified understanding of the diversity within Islam is also reflected in the ways of explaining the apparent differences in Muslim belief and behaviour by placing them along a single continuum, described in terms like religious/nonreligious, radical/non-radical, conservative/liberal and extreme/non-extreme. For instance, the success of Islamic education teachers in developing trust with different families was explained by one principal in terms of him "not representing either of the extremes". The secular normativity imposed on Muslims, as well as poor knowledge of the existing variety in Islamic sensibilities, can also be seen in demands to "secularize Islam" in order to make it compatible with modern liberal society. As one principal put it, Islam "needs its Martin Luther", who would cut the "sharp edges" of that religion and help Muslims integrate into the West.

Furthermore, the lack of understanding of intra-religious diversity creates issues in practices of governance. The school principals' ways of outsourcing the management of religious diversity by letting a local imam or a single Muslim teacher decide what kinds of adjustments to the school culture need to be made in order to cater to the needs of "the Muslims" can be traced to understandings of Islam as a monolithic 
(and authority-bound) tradition. Principals' efforts to consult imams may be made in good will, but in actuality they can be experienced as an insult. For example, the reactions of Muslim parents to the cases where principals have asked imams to make statements on whether or not certain religious practices should be allowed in school have been strongly negative (Rissanen 2018). One Shia parent referred to a principal's move to consult a local Sunni imam as an experience of being stabbed in the back, and other parents who belonged to the community regarded the act as an indication that they were not considered intelligent enough to make their own decisions.

On the one hand, those Muslim parents who are regarded as well-integrated and moderate are continuously expected to answer questions, take stances "on behalf of Muslims", be experts of their religion, and be able to represent the other Muslim parents in the school. On the other hand, there were also principals who regarded "Muslims" as such a diverse category that it did not have any analytical value-and therefore could be ignored-while any differences among Muslims were treated as individual differences. Considering Islam as "too diverse to be talked about" can be combined with very stereotyping and generalizing views about it (Rissanen 2019). In a way, appealing to the diversity of Islam sometimes becomes an empty mantra, which is not based on adequate knowledge and instead used as an argument to justify the efforts of governance of Islam through the strategy of religion-blindness.

\section{Protestant Conceptions of Religion and Culture}

The third challenge of religious literacy that we have noticed is the naturalization of culture-bound conceptualisations of religion and culture, which indicates a lack of critical cultural self-awareness on the part of educational professionals. Previously, "neutral" and "objective" forms of religious education in the Nordic context have been demonstrated to be deeply influenced by cultural Protestantism but in a way that is not recognised by teachers themselves (Berglund 2014; Slotte 2011). Protestant conceptions of religion and culture also seem to impact the practices of governance of religious diversity in schools. In Finland, as a result of globalization and immigration during recent decades, there has been a shift away from the national narrative of a homogeneous Finnish culture. For instance, the national core curriculum seems to avoid essentialising language by describing Finnish culture as diverse in its essence (NCCBE 2014). However, the naturalization of Protestant conceptions of religion and culture is still prevalent in Finnish society. According to our observations, "Protestant bias" influences interpretations of religion and secularity in the school context, but this bias is rarely recognized.

The problem-centred discourse where Islam is seen as the main challenge for the social order of Finnish society is fostered by expectations that Islam should follow the same foreseeable logic as the Protestant tradition and its canonized doctrines; when it does not, Muslim families can be regarded as "difficult". Furthermore, religion-blind views of Protestantism only as a cultural tradition occasionally lead to disregarding 
the right of non-Christians not to be involved in what they feel is Christian practice. On an everyday level, this can mean, for instance, using the fact that a song is traditional as an argument to support the view that it is not religious. Moreover, statements that "we don't celebrate any religious holidays here" in schools where, for instance, Christmas is an important part of the school culture are good examples of the naturalization of Protestantism (Rissanen 2018, 2019; Ubani forthcoming).

The nature of conceptions of religion and culture can also be identified in the school personnel's perceptions of what are considered to be everyday life practices at school and their interpretation of guardians' and students' decisions. For instance, student participation in school festivities that are based on or have strong references to Christianity is sometimes debated. The end of autumn term traditionally includes a festivity with references to the birth of Jesus, be it in the form of songs, hymns or plays. What often happened in one of the schools studied is that the Muslim students participated in the rehearsals of the songs or plays but then were absent without notice from the school festivity when the presentation took place. In this situation, the teachers emphasised the way in which students do not ask for permission to be absent and the problems this causes when casting students in different roles, with the latter leading Muslim students to constantly be in lesser roles in various school celebrations. Absences without permission also occurred during swimming lessons and city hall receptions with dancing. Those explained as extra day absences due to Eid were interpreted by professionals more as a practical problem or the custom of a certain group in the community than a situation rooted in religious convictions or a sense of not having a voice to negotiate religious rights in school life (Ubani 2018). A "secular Protestant" mind-set also indicates a lack of recognition that religion is an important thing for some students; discourses on the incorporation of religious diversity and religious rights in school often reveal an agenda of "liberalizing students" from the religion-based demands of their parents and religious communities, revealing an underlying assumption that religion is not a significant identity factor for young people (Rissanen 2018).

The naturalization of Protestant or Christian elements relates also to the way in which professionals endeavour to promote tolerance through emphasising the similarities in all religions. In reality, however, views concerning the "common basis of all religions" may be based on looking at religion through a Christian lens. This was exemplified by one principal who quoted Jesus' words from the Bible ("let all the children come to me") to demonstrate that all religions promote the same positive values. However, only putting emphasis on the commonalities of religions and holding the view that other religions are in harmony with the core of Protestantism, since this tradition represents the "essence" of humanity, indicate a lack of religious literacy and can be seen as a form of cultural minimization and a religion-blind way of dealing with diversity (Rissanen 2019). 


\section{Conclusion}

While discussions on the correct representation and treatment of religions as part of religious or intercultural education has been a much researched and discussed issue, resulting in Europe-wide recommendations for policy and practice (e.g. Jackson 2014; OSCE/ODIHR 2007), in this chapter our key argument has been that more attention needs to be paid to religion in the wider school culture, and that all educators-not only those teaching about religions_-need religious literacy in order to be able to develop equal and impartial practices for the governance of religious diversity. In Finland, recent reports have adduced the inadequate adaptation of schools and teacher education to the changed demographics (Tainio and Kallioniemi 2019; Räsänen et al. 2018). We perceive schools and their personnel as official representatives of Finnish society for religious, ethnic and cultural minorities in particular, and the school essentially as a socialisation tool implementing state policies vis-à-vis its citizens (Windzio 2013; Weymann, 2010, 2013). For these reasons, the question of religious literacy of principals and teachers is an essential aspect to be highlighted when evaluating and developing the governance of religion policies of the Finnish state. In addition to intra-school culture, there is also a growing need and demand for connecting the school more closely to the surrounding community and communities (Jackson 2014); these aspects have also been recognised in the recent national core curricula in Finland (i.e. NCCBE 2014). In a post-secular context this seems to require a new kind of understanding and discernment regarding the global, societal, cultural, communal and individual aspects of religion (Ubani 2019), as has been pointed out by Dinham and Francis (2015) and Moore (2015).

Based on our case studies, we have detected certain key challenges in educators' religious literacy: these relate to perceptions concerning intra-religious diversity, the distinction between religion and culture, and Protestant conceptions of religion and culture. The case examples reveal education professionals' difficulties in recognising when religion is a relevant factor in the behaviour and interaction of different members of the school community - and when it is not. In other words, our examples depict both 'religionisation' and 'religion-blindness' as reflections of religious illiteracy. Examples of religionisation include attributing to religion some (negatively perceived) behaviours of members of a certain ethnic group, as well as not recognising features of the minority tradition as "cultural heritage" but instead as essentially religious. Examples of religion-blindness include moving certain behaviours beyond the realm of religious freedom by interpreting them as cultural, not recognising religion as a relevant identity factor of some of the students, holding religion-blind views of the majority religion as only a cultural tradition, and naturalizing culture-bound conceptualisations of the majority religion.

In other words, majority religion (Lutheranism) is often "culturalised" and minority religion (Islam) "religionised", with the exception that sometimes the behaviours or needs of religious minority members are "culturalised" in order to legitimize the view that declining to accommodate these needs does not insult anyone's religious rights. Thus, religionisation and religion-blindness sometimes appear as 
intentional strategies for legitimizing policies of everyday governance of religious diversity, but they also seem to originate from three areas where a deficit of religious literacy is evident: a lack of knowledge about the internal diversity of religions, problems in understanding the complex intersections of religion and culture, and a lack of cultural self-awareness. Thus, we argue that the advancement of education professionals' religious literacy in these three areas is needed in order to ensure that they are able to develop impartial practices of governance (Jackson 2014) that do not arouse feelings of exclusion among religious minorities; generally, in pre-service and in-service teacher education, attention should be paid to religious literacy as a vital component of educators' intercultural competence.

The development of "intercultural understanding" may be an insufficient approach when it comes to providing tools for handling religion in public schools today. As the examples presented in this chapter demonstrate, the reductionist treatment of religion as a form of cultural diversity does not advance religious literacy, and it may even lead to neglect of the specific challenges in encountering religious diversity and incorporating religious identities (see also Rissanen et al. 2016; Rissanen 2018). However, even though the education of teachers' and principals' competences to deal with religious diversity has for a long time lagged behind rapid changes in the social reality in Finland, recent years have witnessed several educational initiatives that focus on the development of educational professionals' intercultural competence and also recognise religious diversity as an essential topic to deal with (Räsänen et al. 2018). To support and fuel these initiatives, several research projects funded by the Ministry of Education are under way.

\section{References}

Barnes, L. Philip. (2006). The misrepresentation of religion in modern British (religious) education. British Journal of Educational Studies, 54(4), 395-411.

Bell, S., \& Hindmoor, A. (2009). Rethinking Governance: The centrality of the state in modern society. Cambridge: Cambridge University Press.

Berglund, J. (2014). Swedish religion education: Objective but Marinated in Lutheran Protestantism? Temenos-Nordic Journal of Comparative Religion, 49(2), 165-184.

Berglund, J. (2017). Secular normativity and the religification of Muslims in Swedish public schooling. Oxford Review of Education, 43, 524-535.

Berry, Laura B., \& Southwell., L. (2011). Developing intercultural understanding and skills: Models and approaches. Intercultural Education, 22, 453-466.

Biesta, G., Aldridge, D., Hannam, P., \& Whittle, S. (2019). Religious literacy: A Way forward for religious education? A report submitted to the Culham St Gabriel's Trust. Brunel University London \& Hampshire Inspection and Advisory Services. Retrieved November 27, 2019, from https://www.reonline.org.uk/wp-content/uploads/2019/07/Religious-LiteracyBiesta-Aldridge-Hannam-Whittle-June-2019.pdf.

Buchardt, M., Markkola, P., \& Valtonen, H. (2013). Introduction: Education and the making of the Nordic welfare states. In M. Buchardt, P. Markkola, \& H. Valtonen (Eds.), Education, state and citizenship (pp. 7-30). NordWel Studies in Historical Welfare State Research 4. Helsinki: Nordic Centre of Excellence NordWell. 
Dinham, A., \& Francis, M. (2015). Religious literacy: Contesting and idea and practice. In A. Dinham \& M. Francis (Eds.), Religious literacy in policy and practice (pp. 3-26). Bristol: Policy Press.

Fagioli-Ndlovu, M. (2015). Somalis in Europe. Robert Schuman Centre for Advanced Studies. San Dominico di Fiesole, Italy: European University Institute.

Husu, J., \& Toom, A. (2012). Finnish teachers as "Makers of many": Balancing between broad pedagogical freedom and responsibility. In H. Niemi, A. Kallioniemi, \& A. Toom (Eds.), Miracle of education: The principles and practices of teaching and learning in Finnish schools (pp. 39-54). Rotterdam: Sense.

Jackson, R. (2014). 'Signposts': Policy and practice for teaching about religions and non-religious worldviews in intercultural education. Strasbourg: Council of Europe Publishing.

Kuusisto, E., Tirri, K., \& Rissanen, I. (2012). Finnish teachers' ethical sensitivity. Education Research International, 2012. http://dx.doi.org/10.1155/2012/351879

Migrant Integration Policy Index. (2015). Retrieved November 10, 2017, from http://www.mip ex.eu/.

Moore, D. L. (2015). Diminishing religious literacy: Methodological assumptions and analytical frameworks for promoting the public understanding of religion. In A. Dinham \& M. Francis (Eds.), Religious literacy in policy and practice (pp. 27-38). Bristol: Policy Press.

Multiculturalism Policy Index. (2010). Retrieved November 10, 2017, from http://www.queensu. $\mathrm{ca} / \mathrm{mcp} /$.

Mundy, K. (2007). Global governance, educational change. Comparative Education, 43(3), 339_ 357.

Mäkelä, M.-L., Kalalahti, M., \& Varjo, J. (2017). Monikulttuurinen suomalainen peruskoulu? Monikulttuurisuus peruskoulun opetussuunnitelmissa 1990-2010 luvuilla. Kasvatus \& Aika, 11(4), 22-38.

National Core Curriculum for Basic Education 2004. (2004). Helsinki: Opetushallitus.

National Core Curriculum for Basic Education 2014. (2014). Opetushallitus, määräykset ja ohjeet, 96. Helsinki: Opetushallitus.

Nynäs, P., Illman, R., \& Martikainen, T. (2015). Rethinking the place of religion in Finland. In P. Nynäs, R. Illman, \& T. Martikainen (Eds.), On the outskirts of 'the Church': Diversities, fluidities and new spaces of religion in Finland (pp. 11-28). Zürich: Lit Verlag.

OSCE/ODIHR. (2007). The Toledo guiding principles on teaching about religions and beliefs in public schools. http://www.osce.org/item/28314.html

Poulter, S., Riitaoja, A.-L., \& Kuusisto, A. (2016). Thinking multicultural education 'Otherwise'-From a secularist construction towards a plurality of epistemologies and worldviews. Globalisation, Societies and Education, 14(1), 68-86.

Revell, L. (2012). Islam and education: The manipulation and misrepresentation of a religion. Stoke on Trent: Trentham Books.

Rissanen, I. (2018). Negotiations on inclusive citizenship in a post-secular school: Perspectives of "cultural broker" Muslim parents and teachers in Finland and Sweden. Scandinavian Journal of Educational Research, 64(1), 135-150. https://doi.org/10.1080/00313831.2018.1514323.

Rissanen, I. (2019). School principals' diversity ideologies in fostering the inclusion of Muslims in Finnish and Swedish schools. Race, Ethnicity and Education. https://doi.org/10.1080/13613324. 2019.1599340.

Rissanen, I., Kuusisto, E., \& Kuusisto, A. (2016). Developing teachers' intercultural sensitivity: Case study on a pilot course in Finnish teacher education. Teaching and Teacher Education, 59, 446-456.

Rissanen, I., Kuusisto, E., \& Tirri, K. (2015). Finnish teachers' attitudes to Muslim students and Muslim student integration. Journal for the Scientific Study of Religion, 54(2), 277-290.

Rissanen, I., Ubani, M., \& Poulter, S. (2019). Key issues of secularisation, pluralism and dialogue in Finnish public education. In M. Ubani, I. Rissanen, \& S. Poulter (Eds.), Contextualising dialogue, secularisation and pluralism: Religion in Finnish public education (pp. 203-216). Münster: Waxmann. 
Roy, O. (2010). Holy ignorance: When religion and culture part ways. London: Hurst \& Company.

Räsänen, R., Jokikokko, K., \& Lampinen, J. (2018). Kulttuuriseen moninaisuuteen liittyvä osaaminen perusopetuksessa. Kartoitus tutkimuksesta sekä opetushenkilöstön koulutuksesta ja osaamisen tuesta. Raportit ja selvitykset 2018(6). Helsinki: Opetushallitus.

Sakaranaho, T. (2013). Religious education in Finland. Temenos-Nordic Journal of Comparative Religion, 49(2), 9-35.

Sakaranaho, T. (2018). Encountering religious diversity: Multilevel governance of Islamic education in Finland and Ireland. Journal of Religious Education, 66(2), 111-124.

Sakaranaho, T. (2019). The governance of religious education in Finland: a state-centric relational approach? In M. Ubani, I. Rissanen, \& S. Poulter (Eds.), Contextualising dialogue, secularisation and pluralism: Religion in Finnish public education (pp. 17-37). Münster: Waxmann.

Sakaranaho, T., \& Martikainen, T. (2015). The governance of Islam in Finland and Ireland. Journal of Religion in Europe, 8(1), 7-30.

Slotte, P. (2011). Securing freedom whilst enhancing competence: The "Knowledge about Christianity, religions and life stances" subject and the judgment of the European court of human rights. Religion and Human Rights, 6, 41-73.

Tainio, L., \& Kallioniemi, A. (Eds.). (2019). Koulujen monet kielet ja uskonnot. Selvitys vähemmistöäidinkielten ja-uskontojen sekä suomi ja ruotsi toisena kielenä-opetuksen tilanteesta eri koulutusasteilla. Valtioneuvoston selvitys- ja tutkimustoiminnan julkaisusarja 11/2019. Helsinki: Valtioneuvosto.

Torfing, J. (2007). Introduction: democratic network governance. In M. Marcussen \& J. Torfing (Eds.), Democratic network governance in Europe (pp. 1-22). Basingstoke: Palgrave Macmillan.

Ubani, M. (2012). Monoreligious education in a pluralist framework: The case of Jewish RE in Finland. Religious Education Journal of Australia, 28(2), 16-25.

Ubani, M. (2013). Threats and solutions: Religion and multiculturalism in educational policy. Intercultural education, 24(3), 195-210.

Ubani, M. (2015). Uskonto ja ryhmäidentiteetit koulun arjessa. In E. Hellqvist, M. Hietamäki \& P. Pihkala (Eds.), Uskonto ja identiteettipolitiikka, (pp. 71-84). Helsinki: Suomalainen Teologinen Kirjallisuusseura.

Ubani, M. (2018). When teachers face religion in public education: Case examples from Finnish public education. Journal of Religious Education, 66(2), 139-150. https://doi.org/10.1007/s40 839-018-0064-x.

Ubani, M. (2019). Religion, multiculturalism and Finnish schools: the secularist-multiculturalist transition. In M. Ubani, I. Rissanen, \& S. Poulter (Eds.), Contextualising dialogue, secularisation and pluralism: Religion in Finnish public education (pp. 105-126). Münster: Waxmann.

Ubani, M. (forthcoming). Religion, multiculturalism and conflict in Finnish educational policy and practice. Manuscript.

Ubani, M., \& Ojala, E. (2018). Introduction. Journal of Religious Education, 66(2), 79-83. https:// doi.org/10.1007/s40839-018-0067-7.

Varjonen, S., Nortio, E., Mähönen, T., \& Jasinskaja-Lahti, I. (2017). Negotiations of immigrants' cultural citizenship in discussions among majority members and immigrants in Finland. Qualitative Psychology, 5(1), 85-98. https://doi.org/10.1037/qup0000074.

Vitikka, E., Krokfors, L., \& Hurmerinta, E. (2012). The finnish national core curriculum: Structure and development. In H. Niemi, A. Toom, \& A. Kallioniemi (Eds.), Miracle of education (pp. 8396). Rotterdam: Sense.

Weymann, A. (2010). The educating state: Historical developments and current trends. In K. Martens, A.-K. Nagel, M. Windzio, \& A. Weyman (Eds.), Transformation of education policy (pp. 53-73). Basingstoke: Palgrave Macmillan.

Weymann, A. (2013). Integration and the education state: Institutional history and public discourse in England, France, Germany, and the US. In M. Windzio (Ed.), Integration and inequality in educational institutions (pp. 21-41). Dordrecht, New York: Springer. 
Windzio, M. (2013). Integration and inequality in educational institutions: An institutional perspective. In M. Windzio (Ed.), Integration and inequality in educational institutions (pp. 3-18). Dordrecht, New York: Springer.

Wright, A. (2004). Religion, education and post-modernity. London: Routledge Falmer.

Zilliacus, H., Paulsrud, B. A., \& Holm, G. (2017). Essentializing vs. non-essentializing students' cultural identities: Curricular discourses in Finland and Sweden. Journal of Multicultural Discourses, 12(2), 166-180. https://doi.org/10.1080/17447143.2017.1311335.

Open Access This chapter is licensed under the terms of the Creative Commons Attribution 4.0 International License (http://creativecommons.org/licenses/by/4.0/), which permits use, sharing, adaptation, distribution and reproduction in any medium or format, as long as you give appropriate credit to the original author(s) and the source, provide a link to the Creative Commons license and indicate if changes were made.

The images or other third party material in this chapter are included in the chapter's Creative Commons license, unless indicated otherwise in a credit line to the material. If material is not included in the chapter's Creative Commons license and your intended use is not permitted by statutory regulation or exceeds the permitted use, you will need to obtain permission directly from the copyright holder.

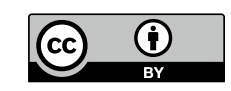

